\title{
In vivo regulation of plasminogen function by plasma carboxypeptidase $B$
}

\author{
Carmen M. Swaisgood, ${ }^{1}$ Detlef Schmitt, ${ }^{2}$ Dan Eaton, ${ }^{2}$ and Edward F. Plow ${ }^{1}$ \\ ${ }^{1}$ Department of Molecular Cardiology, Cleveland Clinic Foundation, Cleveland, Ohio, USA \\ ${ }^{2}$ Department of Protein Chemistry, Genentech, Inc., South San Francisco, California, USA
}

\begin{abstract}
The major functions of plasminogen (Plg) in fibrinolysis and cell migration depend on its binding to carboxy-terminal lysyl residues. The ability of plasma carboxypeptidase $\mathrm{B}(\mathrm{pCPB})$ to remove these residues suggests that it may act as a suppressor of these Plg functions. To evaluate this role of $\mathrm{PCPB}$ in vivo, homozygote $\mathrm{PCPB}$-deficient mice were generated by homologous recombination, and the resulting $\mathrm{pCPB} \mathrm{CP}^{-/-}$mice, which were viable and healthy, were mated to $\mathrm{Plg}^{-/-}$mice. $\mathrm{Plg}^{+/-}$mice show intermediate levels of fibrinolysis and cell migration compared with Plg wild-type and deficient mice, reflecting the intermediate levels of the Plg antigen in their plasma. Differences in Plg-dependent functions between $p C P B^{+/+}, p C P B^{+/-}$, and $p C \mathrm{~PB}^{-/-}$mice were then analyzed in a $\mathrm{Plg}^{+/-}$background. In a pulmonary clot lysis model, fibrinolysis was significantly increased in mice with partial $\left(p C P B^{+/-}\right)$or total absence $\left(p C P B^{-/-}\right)$of $\mathrm{pCPB}$ compared with their wild-type counterparts $\left(p \mathrm{CPB}^{+/+}\right)$. In a thioglycollate model of peritoneal inflammation, leukocyte migration at 72 hours increased significantly in $\mathrm{Plg}^{+/-} / \mathrm{PCPB}{ }^{+/-}$and $\mathrm{Plg}^{+/-} / \mathrm{PCPB}^{-/-}$compared with their wild-type counterparts. These studies demonstrate a definitive role of $\mathrm{PCPB}$ as a modulator of the pivotal functions of Plg in fibrinolysis and cell migration in vivo.
\end{abstract}

J. Clin. Invest. 110:1275-1282 (2002). doi:10.1172/JCI200215082.

\section{Introduction}

Plasma carboxypeptidase B (pCPB) was first isolated from human plasma as a plasminogen-binding (Plgbinding) protein with homology to pancreatic carboxypeptidase B (1). Also known as CPU $(2,3)$, CPR (4), and thrombin-activable fibrinolysis inhibitor (TAFI) (5), PCPB is made by the liver $(1,6,7)$ and is secreted as an approximately $56-\mathrm{kDa}$ zymogen (pro$\mathrm{pCPB})$, which can be proteolytically activated $(1,5$, 8-11) to an enzyme capable of removing carboxy-terminal argininyl and lysyl residues (12). Activation can be initiated by thrombin or plasmin, although the thrombin/thrombomodulin complex is likely to be the primary physiological activator of pro-pCPB (9). The specificity of $\mathrm{pCPB}$ for basic amino acids has a particularly important impact upon the functions of $\mathrm{Plg}$. As verified from the characterization of the $\mathrm{Plg}$ deficient mouse, Plg has a broad physiological and pathophysiological role; it is essential for efficient fibrinolysis (13-15) and facilitates cell migration (16-19). These activities depend upon the capacity of Plg to

Received for publication January 18, 2002, and accepted in revised form August 27, 2002

Address correspondence to: Edward F. Plow, Department of Molecular Cardiology, Cleveland Clinic Foundation, 9500 Euclid Avenue, NB50, Cleveland, Ohio 44195, USA. Phone: (216) 445-8200; Fax: (216) 445-8204;

E-mail: plowe@ccf.org.

Conflict of interest: No conflict of interest has been declared. Nonstandard abbreviations used: plasma carboxypeptidase $B$ (pCPB); plasminogen (Plg); thrombin-activable fibrinolysis inhibitor (TAFI); lysine binding sites (LBS); potato carboxypeptidase inhibitor (PCI); plasma carboxypeptidase $\mathrm{N}$ $(\mathrm{CpN})$; activated protein C (APC); embryonic stem (ES). bind fibrin and cell surfaces via its lysine binding sites (LBS) (20-26). The interaction of the LBS of Plg with carboxy-terminal lysines in its substrates enhances its activation to plasmin and protects the enzyme from inactivation by $\alpha 2$-antiplasmin (27). Partial degradation of substrates by plasmin exposes additional carboxy-terminal lysines augmenting plasminogen activation and, consequently, fibrinolysis or pericellular proteolysis. The ability of $\mathrm{PCPB}$ to remove these specific residues from proteins has made it a prime candidate for modulating the functions of Plg (28). Indeed, it has been shown in in vitro experiments that pCPB inhibits Plg activation and prolongs fibrinolysis $(5,9,12,28)$ by removal of Plg-binding sites from degrading fibrin (10). On the other hand, $\mathrm{PCPB}$ can attenuate systemic Plg activation dependent on $\mathrm{Plg}$ binding to circulating fibrin fragment $\mathrm{E}$ (29). The influence of $\mathrm{PCPB}$ on Plg is not restricted to fibrinolysis. By removal of carboxy-terminal lysines from cell surfaces, $\mathrm{pCPB}$ suppresses Plg binding to cell surfaces (28), which may influence the role of these interactions in cell migration.

Although most data pointing to a role of $\mathrm{PCPB}$ in the regulation of fibrinolysis have been derived from in vitro studies, some in vivo studies also support the physiological functions of PCPB. Redlitz et al. (30) showed that a potato carboxypeptidase inhibitor-sensitive (PCI-sensitive) activity (PCI inhibits PCPB but not the other major and constitutively active basic carboxypeptidase of blood, plasma carboxypeptidase $\mathrm{N}$ $[\mathrm{CpN}]$ ) was activated in dogs with an induced coronary thrombosis, and an inverse correlation was found between the extent of carboxypeptidase activity and 
the time for t-PA to restore blood flow, i.e., a suppression of fibrinolysis. Using a rabbit model of jugular vein thrombolysis, Minnema et al. (31) showed that neutralization of factor XI and inhibition of PCPB enhanced thrombolysis. This observation is consistent with the hypothesis forwarded by Von dem Borne et al. (32) that activation of factor XI generates thrombin, which protects fibrin clots from lysis by activating propCPB. Other in vivo studies have shown that inhibition of PCPB with PCI potentiated thrombolysis $(33,34)$. On the other hand, activated protein C (APC) was shown to prevent death in a thrombin-induced thromboembolism model in mice (35). This effect of APC may depend upon the suppression of additional thrombin generation, which would result in activation of $\mathrm{PCPB}$. In humans, $\mathrm{PCPB}$ levels correlate with clot lysis time in healthy individuals (36) and with an increased risk of deep vein thrombosis (37). Thus, pCPB may serve as an important link between the coagulation and fibrinolytic systems.

To study the role of $\mathrm{pCPB}$ on the modulation of $\mathrm{Plg}$ functions in vivo, $P C P B$ homozygote-deficient $p C P B^{-/-}$ mice were generated and mated to $\mathrm{Plg}^{-1-}$ mice to produce a battery of $\mathrm{Plg} / \mathrm{pCPB}$ genotypes. $\mathrm{Plg}^{+/-}$mice exhibit intermediate levels of fibrinolysis and cell migration between wild-type and deficient mice, reflecting the intermediate levels of Plg in the plasma of these mice (14). We hypothesized that in this setting in which the $\mathrm{Plg}$ system is already compromised, the role of $\mathrm{PCPB}$ in influencing the functions of $\mathrm{Plg}$ might be accentuated and most readily demonstrated. Our studies establish a definitive role of $\mathrm{PCPB}$ as a modulator of the functions of Plg in fibrinolysis and cell migration in vivo.

\section{Methods}

$p C P B$ gene structure. Two gene fragments containing $P C P B$ sequence were isolated from a mouse $129 \mathrm{SV}$ Lambda Dash II genomic library. These clones contained nucleotides 146-1,394 of the mouse PCPB cDNA sequence. Two additional clones were isolated from a bacterial artificial chromosome mouse genomic library that contained nucleotides $1-145$ of the mouse PCPB cDNA sequence (Genbank accession number AF164524) (7). Taken together, the complete mouse $p C P B$ gene contained 10 exons.

Construction of the gene-targeting vector. To target the murine $P C P B$ gene, a replacement-type targeting vector was constructed in which a neomycin gene was inserted into exon 2 (see Figure 1a). An 18-kb gene fragment containing base number 146-794 of the mouse $\mathrm{PCPB}$ cDNA sequence was isolated from the genomic library. The gene fragment was subcloned into pBluescript II SK (Stratagene, La Jolla, California, USA), and an 8.4$\mathrm{kb}$ BamHI/BglII fragment was derived from the subclone. This fragment contained pBluescript II SK vector, bases $146-272$ of exon 2 , and the $2.5-\mathrm{kb}$ intron region flanking each side of the exon (Figure 1a). A unique SalI site located within the $P C P B$ exon was converted into a cloning site that contained restriction sites for ApaI and NotI. The neomycin resistant gene (neo) was inserted into the newly created NotI site in reverse orientation to the $P C P B$ gene. The herpes simplex virus thymidine kinase $(t k)$ gene was inserted into the MfeI site at the $5^{\prime}$ end of the genomic clone. The targeting vector was linearized using AvrII (Figure 1a).

Generation of chimeric and $P C P B$-deficient mice. The targeting vector was electroporated into gelatin-adapted R1 embryonic stem (ES) cells, and stable transfectants were selected as described (38). Clones containing the disrupted $P C P B$ gene were identified by Southern blot analysis and PCR. Homologous integration was observed in 27 out of 728 (3.7\%) clones. Genomic DNA from wild-type cells yielded an approximately 9-kb fragment after ApaI digestion (see Figure 1b), whereas the disrupted gene produced a $4.3-\mathrm{kb}$ fragment. Thus, in heterozygous cells, both a $9-\mathrm{kb}$ and a $4.3-\mathrm{kb}$ band were observed (Figure 1b). Two independent clones that had undergone homologous recombination were injected into C57BL/ 6 host blastocysts as described by Bradley (39). Male chimeras were selected and bred with C57BL/6 mice for gene transmission. Heterozygote and homozygote $p C P B$-deficient mutants were identified by PCR analysis of tail tip genomic DNA. Heterozygote males were backcrossed with C57BL/6 mice for six additional generations.

Southern blot analysis. Genomic DNA was isolated from cultured ES cells and tail tips as described previously (40) and digested with ApaI. Southern blot analysis was performed as described by Sambrook (41). To screen for ES cell colonies and animals harboring the recombined gene, an 80-mer probe was used, which aligned to the intron region between the ApaI restriction site and the $3^{\prime}$ end of the gene-targeting vector ( 3 in Figure 1a).

PCR analysis. Heterozygote and homozygous PCPBdeficient mutants were identified using a neo primer and a PCPB-specific primer designed to the first exon sequence $3^{\prime}$ of the gene-targeting vector. The neo-specific primer (2a in Figure 1a) was TTG TGT AGC GCC AAG TGC CCA G, and the $P C P B$ specific primer was $(2 \mathrm{~b}$ in Figure 1a) AGT CTG CTG TTC AAT TAG GTC CTC CAC G. PCR analysis of the disrupted gene produced a 2.5 -kb fragment in $p C \mathrm{CPB}^{-/-}$and $p C P B^{+/-}$mice, whereas wild-type genomic DNA did not amplify a fragment of this size (Figure 1c). Homozygote animals were verified by an additional PCR with an exon primer pair situated $5^{\prime}$ and $3^{\prime}$ of the neo insertion site that amplified a 120-bp fragment in $p C P B^{+/+}$and $p C P B^{+/-}$mice only (see Figure 1c): primer 1a (Figure 1a), TGG CAG CCA GTG ACA GCT GAA TTC ATC G; primer 1b (Figure 1a), CGT ACT TAA ATG GAA TTC TGC TCA CAT TTA AAT GCG C. A 50- $\mu$ l PCR reaction was performed using the Advantage cDNA PCR Kit (CLONTECH Laboratories Inc., Palo Alto, California, USA).

Northern blot analysis. Total RNA was isolated from 6week-old mouse livers of $p \mathrm{CPB}^{+/+}, p \mathrm{CPB}^{+/-}$, and $p \mathrm{CPB}^{-/-}$ mice using TRIzol Reagent (Invitrogen Life Technologies, Carlsbad, California, USA). Approximately $30 \mu \mathrm{g}$ of RNA was separated on an agarose-formaldehyde gel 
and blotted as described by Sambrook (41). The hybridization was performed using a 600-bp randomlabeled $p C P B$ DNA fragment. In addition, the blot was stripped and rehybridized with a GAPDH probe to show equal loading.

Generation of $\mathrm{Plg} / \mathrm{PCPB}$ mice. $\mathrm{Plg}^{-/-}$mice were developed and characterized as described previously (14). $\mathrm{Plg}^{-1-}$ mice $(\mathrm{C} 57 \mathrm{BL} / 6 / 129 \mathrm{SVJ})$ were mated to $p \mathrm{CPB}^{-/-}$mice $(\mathrm{C} 57 \mathrm{BL} / 6)$ to produce $\mathrm{Plg}^{+/-} / \mathrm{PCPB} \mathrm{B}^{+/-}$mice $\left(\mathrm{F}_{1}\right)$, and these mice were mated to their siblings to produce the variety of $P l g / P C P B$ genotypes $\left(\mathrm{F}_{2}\right)$ used. Genotyping for $\mathrm{Plg}$ was determined either by Southern blot or PCR analysis as described (14). Mice were housed in microisolator cages on a 12-hour day/night cycle and fed regular chow diet. Experimental mice were 8-12 weeks of age, of mixed gender, and appeared healthy during the course of the experiments. In all experiments, comparisons were made between littermates. All animal protocols were approved by the Institutional Animal Research Committee.

Determination of $P C P B$ activity and protein in plasma. Murine $\mathrm{PCPB}$ plasma activity and protein levels were determined using a chromogenic assay (Actichrome Plasma TAFI Activity Kit; American Diagnostica Inc., Greenwich, Connecticut, USA) or an ELISA. Briefly, blood collected by cardiac puncture into $3.8 \%$ trisodium citrate was centrifuged ( $100 \mathrm{~g}, 15$ minutes), and the plasma was incubated with a TAFI activation reagent, which contains the thrombin/thrombomodulin complex that converts pro-pCPB to its active form. The activated plasma was then assayed for total carboxypeptidase and $\mathrm{CpN}$ in the presence of PCI according to the manufacturer's instructions. The difference in color development between the total carboxypeptidase activity and the $\mathrm{CpN}$ activity represents activated $\mathrm{PCPB}$. This difference was compared with values generated by an activated $\mathrm{PCPB}$ standard curve. The ELISA was performed using a kit designed for the detection of human pCPB (Enzyme Research Laboratories, South Bend, Indiana, USA), with purified human $\mathrm{PCPB}$ as a standard.

Determination of Plg antigen in plasma. Quantitative determination of Plg antigen levels in plasma of mice was performed by ELISA using a purified rabbit polyclonal $\mathrm{Ab}$ against murine $\mathrm{Plg}$ (courtesy of Tor Ny, University of Umea, Umea, Sweden), and isolated murine plasminogen was used for calibration.

Fibrinolysis in vitro. Clots were formed from $1 \mathrm{ml}$ of human plasma immuno-

depleted of $\mathrm{pCPB}$ as described previously (28) to which $50 \mu \mathrm{l}$ PBS (or PCI), $15 \mu \mathrm{l}$ of $1 \mathrm{M} \mathrm{CaCl}_{2}, 15 \mu \mathrm{l}^{125} \mathrm{I}$-fibrinogen $\left(\sim 5 \times 10^{6} \mathrm{cpm}\right)$, and $3 \mu$ thrombin $(0.2 \mathrm{U} / \mathrm{ml}$, final concentration) were added. The mixture was placed in a microtiter plate $(50 \mu \mathrm{l} /$ well $)$ and incubated for 1 hour at $37^{\circ} \mathrm{C}$. The wells were emptied, and the clots were washed twice with PBS. Clot lysis was carried out using $1 \mathrm{ml}$ of pooled plasma from $p C P B^{+/+}$or $\mathrm{PCPB}^{-/-}$mice containing $50 \mu \mathrm{l}$ PBS or PCI, $5 \mu \mathrm{l}$ heparin, and $25 \mu \mathrm{lt}-\mathrm{PA}(1 \mu \mathrm{g} / \mathrm{ml}$, final concentration). The above mixture $(200 \mu \mathrm{l} /$ well $)$ was added to wells containing the clots and incubated for 2 hours. Aliquots $(15 \mu \mathrm{l})$ were taken every 20 minutes and counted.

Fibrinolysis in vivo. Lysis of ${ }^{125}$ I-fibrin mouse plasma clots from $\mathrm{Plg}^{-1-} / \mathrm{PCPB}^{-1-}$ mice injected via the jugular vein was determined as described previously (14) with the following modifications. A ${ }^{125}$ I-fibrin plasma clot, containing $0.1 \mu \mathrm{Ci}$ human ${ }^{125} \mathrm{I}$-fibrinogen, was prepared from $\mathrm{Plg}^{-/-} / \mathrm{PCPB}^{-/-}$mouse plasma and injected into the jugular vein of mice of the selected genotypes.

a
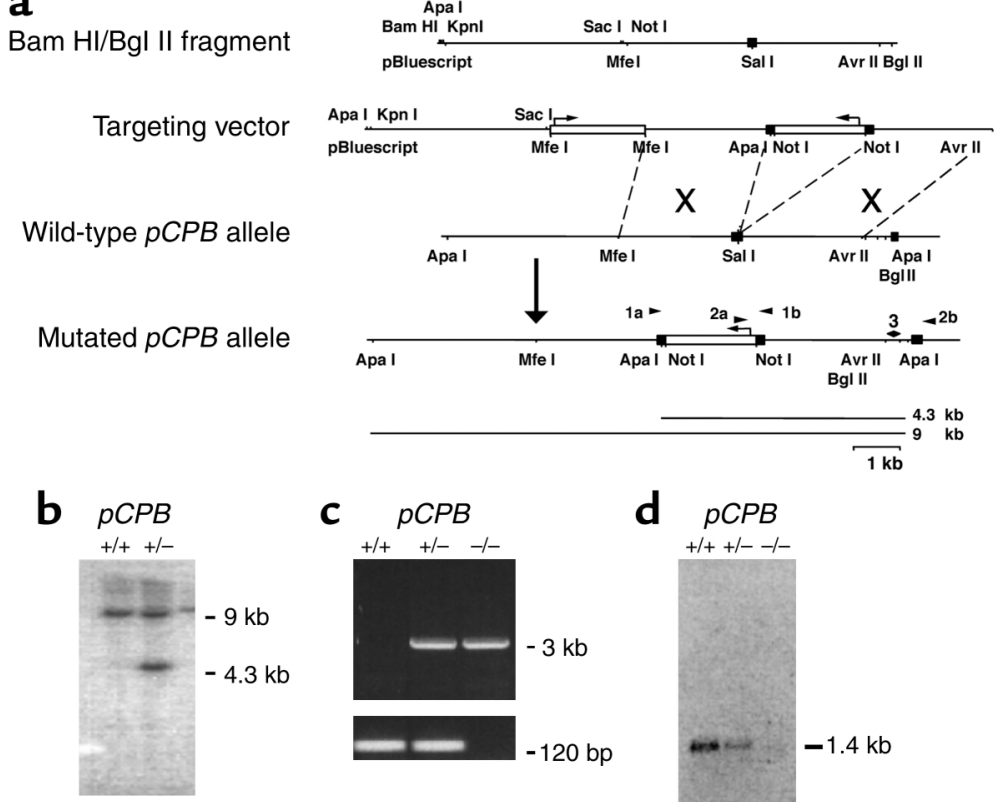

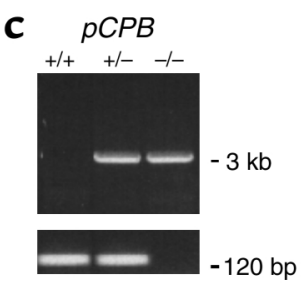

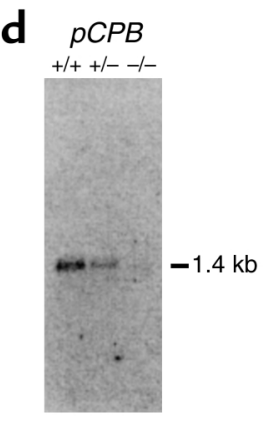

Figure 1

Generation and characterization of $p C P B$-deficient mice. (a) Design of the gene-targeting vector. Upon homologous recombination, a mutated $\mathrm{PCPB}$ allele was created that contained the neo resistance gene inserted in exon 2. (b) Southern blot analysis of $p C P B$ gene disruption in ES cells. The 80-mer probe ( 3 in a) detected an approximately 9-kb fragment from the wild-type allele, whereas the disrupted allele produced a 4.3-kb fragment after Apal digestion of genomic DNA. (c) PCR analysis of mouse tail tip DNA. Mice carrying a mutant $p C P B$ gene were identified using a neo-specific primer $(2 \mathrm{a}$ in $\mathbf{a})$ and a primer located with exon 3 ( $2 \mathrm{~b}$ in a). The PCR amplification produced a product of about $3 \mathrm{~kb}$ in $p C P B^{+/-}$and $p C P B^{-/-}$mice. Homozygote animals were identified by an additional PCR analysis. An exon primer pair situated $5^{\prime}$ ( $1 \mathrm{a}$ in a) and $3^{\prime}$ ( $1 \mathrm{~b}$ in a) of the neo insertion site amplified a 120-bp fragment in $p C P B^{+/+}$and $p C P B^{+/-}$animals only. (d) Northern blot analysis of $p C P B$ transgenic mice. Total RNA was isolated from 6-week-old mouse livers of $p C P B^{+/+}, p C P B^{+/-}$, and $p C P B^{-/-}$ animals. Hybridization with a 600-bp random-labeled $p C P B$ DNA fragment revealed a 1.4$\mathrm{kb}$ band present in $p \mathrm{CPB}^{+/+}$and $p C P B^{+/-}$animals, but absent from $p C \mathrm{~PB}^{-/-}$animals. 


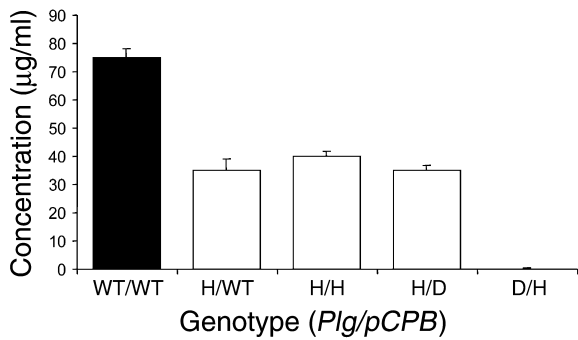

Figure 2

Plasma plasminogen levels among mice with different $p C P B$ genotypes. A competitive ELISA was performed using a rabbit anti-murine $\mathrm{Plg} A b$ and purified murine plasminogen for calibration. Data are mean \pm SEM from $n=3$. WT, wild-type; $H$, heterozygote; $D$, deficient.

Spontaneous clot lysis was determined by measuring the residual radioactivity in the heart and lungs ex vivo 4 hours after injection, and percentage fibrinolysis was defined as the amount of radioactivity that had disappeared compared with the total amount of radioactivity injected.

Peritoneal inflammation model. A thioglycollate inflammation model was used as described previously (17). Mice $(n=7$ per group) of the various genotypes were injected intraperitoneally with $0.5 \mathrm{ml}$ of a $4 \%$ Brewer thioglycollate medium (Difco Laboratories, Detroit, Michigan, USA). At 72 hours, the mice were sacrificed by isofluorane inhalation. The peritoneal cavity was exposed and the exudate collected by washing the cavity with $4 \mathrm{ml}$ of sterile PBS using an 18-gauge catheter. The peritoneal lavage fluid was centrifuged $(1,500 \mathrm{~g}, 10$ minutes). To remove erythrocytes, the cell pellet was subjected to hypotonic lysis. Leukocytes were resuspended in PBS and counted. Cell counts, performed in triplicate on each peritoneal exudate sample, were quantified in a hemocytometer.

Statistical analyses. Values were expressed as means plus or minus SEM. Comparisons were made using student's $t$ test and ANOVA when more than two values were compared. $P$ values less than 0.05 were considered significant.

\section{Results}

Viability, fertility, and the fibrinolytic function of $p C P B-d e f i-$ cient mice. The $\mathrm{PCPB}$-deficient mice were generated using the targeting vector described in Figure 1. Northern blot analysis of RNA prepared from liver of $p C P B^{+/+}$ mice revealed a $\mathrm{PCPB}$-specific mRNA of approximately $1.4 \mathrm{~kb}$ in wild-type and heterozygote mice, whereas no mRNA for $\mathrm{PCPB}$ or a variant form could be detected in $p C P B^{-/-}$mice (Figure 1d). The intensity of the mRNA band from the heterozygote animals was about half that in the wild-type animals (by densitometric scan, 0.85 for wild-type vs. 0.38 for heterozygote, relative to the mRNA for GAPDH in the same lane). Should a resplicing event occur in which the neomycin gene inserted in exon 2 of the targeting vector were deleted, the resulting mRNA of the mutated $\mathrm{pCPB}$ (minus exon 2) would be approximately 1,250 bp; no mRNA of this size was detected on the gel (see Figure $1 \mathrm{~d})$. In addition, as detailed below, no $\mathrm{PCPB}$ activity or antigen was detected in the plasma of these animals. Several general parameters of health were evaluated in the $p C P B^{-/-}$mice, and all appeared to be normal. Life expectancy was normal for $p C P B^{-/-}$mice, with that of both males and females exceeding 19 months of age. Gender distribution was also equal among the $p C P B^{-/-}$ mice. Of $85 \mathrm{pCPB}^{-/-}$mice analyzed, 39 (46\%) were males and $46(54 \%)$ were females. When $p C P B^{-1-}$ females were mated to $p \mathrm{CPB}^{-/-}$males, they produced one to three litters each of $7.7 \pm 0.5$ mice per litter. This litter size is not significantly different from that $(6.7 \pm 0.3)$ obtained from wild-type mice of the same genetic background (C57Bl/6). The $p \mathrm{CPB}^{-/-}$mice exhibit none of the poor health characteristics of the Plg-deficient mice $(14,42)$.

In the absence of an overt phenotype, our analyses were directed to assess the role of $\mathrm{PCPB}$ as a modulator of the functions of Plg. An in vitro clot lysis assay was performed using plasma from $p C P B^{+/+}$or $p C P B^{-/-}$animals. In this assay, PCPB-depleted human plasma was used to make ${ }^{125}$ I-fibrin clots. The clots were washed well, and lysis was measured at various time points after the addition of plasma derived from either $p C P B^{+/+}$or $p C P B^{-/-}$mice and t-PA. At 60 minutes, the extent of clot lysis was $52.8 \% \pm 1.8 \%$ in the pCPB-deficient plasma compared with $49.0 \% \pm 1.5 \%$ in the plasma derived from wild-type mice. Although these differences were modest, they were significant $(P=0.03)$. When PCI, an inhibitor of PCPB, was added to the plasma, fibrinolysis increased to $52.8 \% \pm 1.8 \%$ in the plasma derived from wild-type mice, but did not change in plasma derived from the $p C P B^{-/-}$mice $(54.2 \% \pm 1.1 \%)$.

Generation and characterization of $p \mathrm{CPB}^{-/-}$mice in various Plg backgrounds. We anticipated that the influence of $\mathrm{pCPB}$ as a modulator of Plg might be most apparent in mice under conditions when the Plg system was stressed. Hence, a breeding program was initiated to obtain $\mathrm{PCPB}$ deficiency at variable Plg levels. When $\mathrm{Plg}^{-/-}$males were mated to $\mathrm{PCPB} \mathrm{B}^{-/-}$females $\left(\mathrm{F}_{0}\right)$, they produced one to three litters of $9 \pm 0.4\left(\mathrm{Plg}^{+/-} / \mathrm{PCPB}{ }^{+/-}\right)$ offspring $\left(\mathrm{F}_{1}\right)$ per litter. These $\mathrm{F}_{1}$ mice were then mated to their siblings. Of $117\left(\mathrm{~F}_{2}\right)$ mice analyzed, $30(26 \%)$ were $p C P B^{+/+}, 56(48 \%)$ were $p C P B^{+/-}$, and $31(26 \%)$ were $\mathrm{PCPB}^{-1-}$. This distribution is not significantly different from the expected Mendelian 1:2:1 ratio, indicating equal viability at three weeks of age in $p C P B^{+/+}, p C P B^{+/}$, $p C P B^{-1-}$ mice, regardless of $P l g$ genotype. Life expectan$c y$ and gender distribution in the $P \lg / P C P B$ double-deficient mice were also similar to those found in Plg transgenic mice $(P C P B$ deficiency did not rescue the phenotype observed in $\mathrm{Plg}^{-/}$mice; they were runted, and their described health problems persisted) (14).

To determine if there was a difference in plasma $\mathrm{Plg}$ levels among the different $P C P B$ genotypes, a competitive ELISA was performed using a rabbit anti-murine $\mathrm{Plg} \mathrm{Ab}$, and purified murine plasminogen for calibration. No significant difference was observed in Plg concentration between the three different $p C P B$ genotypes within the same Plg background (Figure 2). Of special note to the experiments described below, Plg levels in 
$p C P B^{+/+}, p C P B^{+/-}$, and $p C P B^{-/-}$were not significantly different in the $\mathrm{Plg}^{+/-}$animals $(P=0.86$ by ANOVA). As previously reported (14), $\mathrm{Plg}^{-/-}$mice had undetectable $\mathrm{Plg}$ levels $(<0.1 \mu \mathrm{g} / \mathrm{ml}$, regardless of $p C P B$ genotype).

To determine the concentration of $\mathrm{PCPB}$ in the plasma of $P l g / p C P B$ mice, a functional assay was performed. In this analysis, total carboxypeptidase activity $(\mathrm{CPN}+\mathrm{pCPB})$ and PCI-inhibitable activity ( $\mathrm{PCPB}$ only) are measured with a chromogenic substrate, and plasma PCPB levels are determined from a standard curve using activated $\mathrm{PCPB}$. No significant differences in $\mathrm{PCPB}$ activity levels were observed in $p C P B^{+/+}$ mice in the three Plg backgrounds, regardless of the strains used (original $P l g$ animals vs. $P l g / P C P B$ mix). However, as expected, no CPI-inhibitable carboxypeptidase activity was observed in $\mathrm{Plg}^{+/-} / \mathrm{pCPB}^{-/-}$mice. The $\mathrm{pCPB}$ levels in plasma of wild-type mice were twofold lower than those found in human plasma $(2.0 \pm 0.25 \mu \mathrm{g} / \mathrm{ml}, n=3$, vs. $4.0 \pm 0.5 \mu \mathrm{g} / \mathrm{ml}, n=3$, respectively). The $p C P B^{+/-}$mice showed intermediate levels of PCPB $(1.25 \pm 0.25 \mu \mathrm{g} / \mathrm{ml}, n=3)$.

In addition, a PCPB ELISA was used to determine pCPB antigen levels in the plasma of these mice. Using purified human $\mathrm{PCPB}$ as a standard, $\mathrm{pCPB}$ levels in the $\mathrm{Plg}^{+++} / \mathrm{PCPB}^{+/+}$mice were slightly higher but not significantly different from those observed in the $\mathrm{Plg}^{+/-} / \mathrm{PCPB}^{+/+}$mice $(1.9 \pm 0.3 \mu \mathrm{g} / \mathrm{ml}, n=4$, vs. $1.4 \pm 0.2$ $\mu \mathrm{g} / \mathrm{ml}, n=3$, respectively). The same was true in the $p C P B^{+/-}$mice in the two different Plg backgrounds $\left(0.8 \pm 0.2 \mu \mathrm{g} / \mathrm{ml}, n=3\right.$, in the $P g^{+/+}$vs. $0.5 \pm 0.1 \mu \mathrm{g} / \mathrm{ml}$, $n=3$, in the $\left.\mathrm{Plg}^{+/-}\right)$, and these levels were about half those found in the $p C P B^{(+/)}$mice regardless of Plg background. The pCPB levels in the $p C P B^{-/-}$mice were similar to background values of the assay $(<0.01 \mu \mathrm{g} / \mathrm{ml})$.

In vivo fibrinolysis in $\mathrm{Plg} / \mathrm{PCPB}$ mice. A pulmonary clot lysis model was used to determine the role of $\mathrm{PCPB}$ as a modulator of fibrinolysis in vivo. This model had been used previously (15) to show that there was essentially no fibrinolysis in $\mathrm{Plg}^{-1-}$ mice after 24 hours compared with complete clot lysis in $\mathrm{Plg}^{+/+}$mice. As shown in Figure 3a, $\mathrm{Plg}^{-1-}$ showed almost no fibrinolysis compared with its wild-type littermates at 4 hours $(2.3 \% \pm 1.1 \%$ vs. $47.6 \% \pm 8.9 \%$ ), consistent with the original report. The $\mathrm{Plg}^{+/-}$mice exhibited an intermediate level of fibrinolysis between wild-type and deficient mice $(20.3 \% \pm 1.5 \%$, $n=6 ; P=0.003$ vs. $P g^{+/+}$; and $P=0.0007$ vs. $\left.\mathrm{Plg}^{-/-}\right)$at this time point (Figure $3 a$ ).

Knowing that the level of fibrinolysis in the $\mathrm{Plg}^{+/-}$ mice could increase or decrease significantly (i.e., could approach the level observed in the $\mathrm{Plg}^{+/+}$or $\mathrm{Plg}^{-/-}$mice), we determined what effect PCPB levels would exert on the extent of clot lysis in this model. As shown in Figure $3 \mathrm{~b}$, fibrinolysis significantly increased in mice with partial $\left(p C P B^{+/-} ; 29.3 \% \pm 3.4 \%, n=5\right)$ or complete deficiency $\left(p C P B^{-/-} ; 54.9 \% \pm 3.7 \%, n=5\right)$ of $\mathrm{pCPB}$ in $\mathrm{Plg}^{+/-}$ mice compared with their wild-type counterparts $\left(p C P B^{+/+}, 20.3 \% \pm 1.5 \%, n=6\right.$; $P<0.0001$, ANOVA) to levels found in $\mathrm{Plg}^{+/+}$animals. There was also a significant difference between $\mathrm{pCPB}^{+/-}$and $\mathrm{PCPB}^{-/-}$in the $\mathrm{Plg}^{+/-}$ background ( $P=0.0009$ by $t$ test), pointing to a gene dosage effect. Thus, total or even partial deficiency of PCPB modulated the fibrinolytic activity of Plg.

If our rationale for conducting these experiments in the $\mathrm{Plg}^{+/-}$mice were correct, i.e., that the reduction in $\mathrm{Plg}$ level would accentuate the effect of PCPB deficiency, then PCPB deficiency should have less effect on fibrinolysis in the $\mathrm{Plg}^{+/+}$background. Accordingly, the pulmonary clot lysis assay was performed in the $\mathrm{pCPB}^{-/}$and $\mathrm{PCPB}^{+/+}$mice in a $\mathrm{Plg}^{+/+}$background. In contrast to the significant effect observed in the $\mathrm{Plg}^{+/-}$mice, no significant difference in fibrinolysis was observed between the two genotypes in the $\mathrm{Plg}^{+/+}$mice $(43.0 \% \pm 6.42 \%, n=4$, in pCPB ${ }^{-/-}$vs. $49.2 \% \pm 6.46 \%, n=4$, in $p C P B^{+/+} ; P=0.52$ ).

In vivo inflammatory response in $\mathrm{Plg} / \mathrm{PCPB}$ mice. In addition to its role in fibrinolysis, Plg facilitates cell migration (reviewed in ref. 18). A manifestation of this function is the suppression of monocyte/macrophage recruitment in $\mathrm{Plg}^{-/-}$mice in response to the intraperitoneal administration of the inflammatory stimulus, thioglycollate (17). We sought to assess whether $P C P B$ deficiency altered this response. Initially, we determined if there was a difference in resident leukocyte levels in the peritoneum among the different $\mathrm{Plg} / \mathrm{p} C P B$ genotypes. At time 0 (uninjected mice), the total number of resident leukocytes in the peritoneum was the same among the mice regardless of $p C P B$ genotype in a $\mathrm{Pl}^{+/-}$background (Figure 4a). Also, no significant difference in the levels of
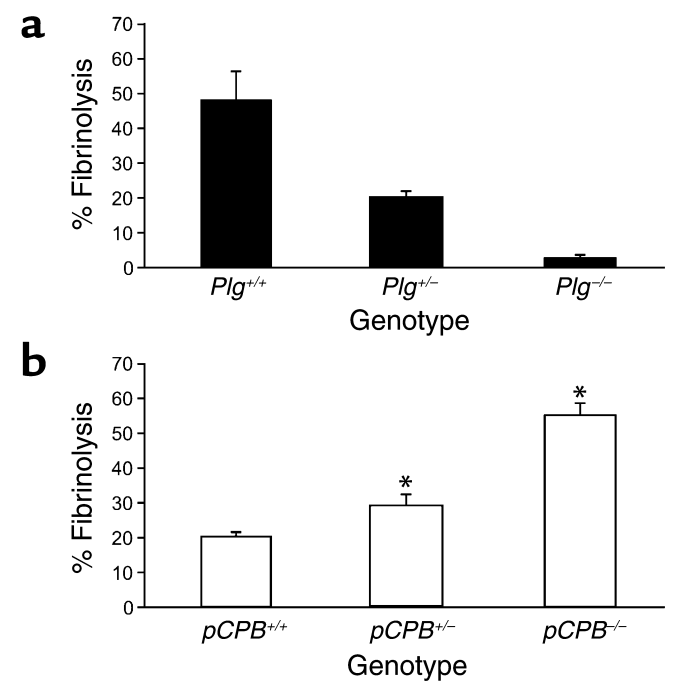

Figure 3

In vivo fibrinolysis in $P / g / p C P B$ mice. A pulmonary clot lysis model was used in which a ${ }^{125} \mathrm{I}$-fibrin clot was injected into the jugular vein of mice. The injected clot embolized primarily to the lungs and heart, and these organs were recovered after 4 hours and counted for radioactivity. The radioactivity in these organs is expressed as a percentage of the injected radioactivity to indicate the extent of fibrinolysis. (a) Fibrinolysis in $\mathrm{Plg}$ transgenic mice. Fibrinolysis in the $\mathrm{P} / \mathrm{g}^{+/-}$ mice $(n=6)$ is significantly different from the $P / g^{+/+}(P=0.003)$ and the $P / g^{-1}(P=0.0007)$ mice by $t$ test. (b) Fibrinolysis in $P / g^{+/-} / p C P B$ transgenic mice $\left(n=5-6\right.$ mice). ${ }^{*} P<0.0001$ compared with $p C P B^{+/+}$ by ANOVA. A significant difference was also found between $p C P B^{+/-}$ and $p C P B^{-/-}$mice in the $P / g^{+/-}$background ( $P=0.0009$ by $t$ test). 
a

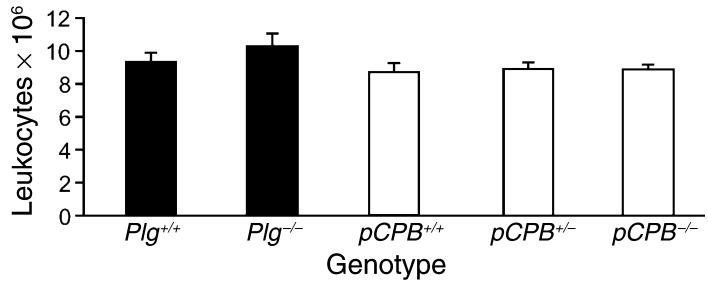

b

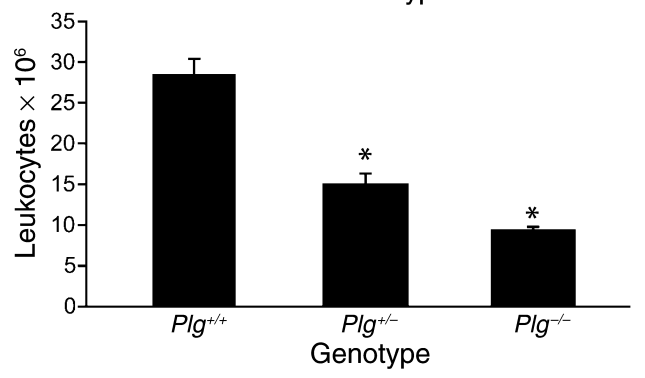

C

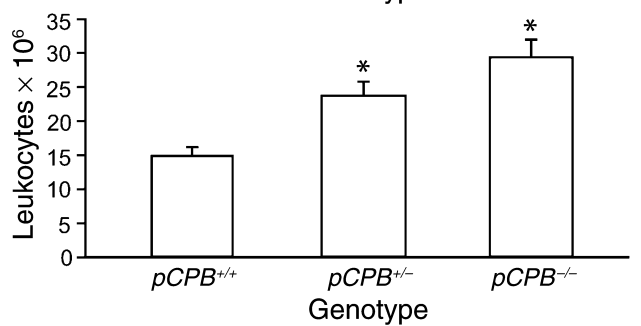

Figure 4

In vivo inflammatory response in $\mathrm{Plg} / \mathrm{pCPB}$ mice. A thioglycollate inflammation model was used in which mice ( $n=7$ per group) were injected intraperitoneally with $0.5 \mathrm{ml}$ of a $4 \%$ Brewer thioglycollate solution. Mice were sacrificed, the peritoneal cavity exposed, and the exudate containing leukocytes was collected and counted. (a) Resident leukocyte levels in the peritoneum among the different $P l g / p C P B$ genotypes at time 0 (uninjected mice). Open bars, $p C P B$ genotypes in a $P / g^{+/-}$background. (b) Total leukocyte levels in Plg transgenic mice 72 hours after thioglycollate injection. ${ }^{*} P<0.0001$ vs. $P / g^{+/+}$. Statistical analysis was performed by $t$ test. (c) Total leukocyte levels in $P / g^{+/-} / P C P B$ transgenic mice 72 hours after thioglycollate injection. ${ }^{*} P=0.0004$ vs. $p C P B^{+/+}$by ANOVA. No significant difference was observed between $P / g^{+/-} / p C P B^{+/-}$and $P / g^{+/-} / p C P B^{-1-}$ mice $(P=0.1722)$ by $t$ test.

resident leukocytes was observed between $\mathrm{Plg}^{+/+}$and $\mathrm{Plg}^{-/}$ mice at time 0 (Figure 4a). At 72 hours after thioglycollate injection, the number of leukocytes in the peritoneum of $\mathrm{Plg}^{+/+}$mice increased three times over basal levels $\left(28.7 \pm 1.62 \times 10^{6}, n=8\right.$, vs. $9.3 \pm 0.56 \times 10^{6}, n=3$, respectively; $P<0.0001$ ) (Figure $4 \mathrm{~b}$ ). However, recruitment of leukocytes into the peritoneum of $\mathrm{Plg}^{-1-}$ was severely compromised and was significantly lower than that observed in the $\mathrm{Plg}^{+/+}$mice $\left(9.34 \pm 0.43 \times 10^{6}, n=5\right.$, vs. $28.7 \pm 1.62 \times 10^{6}, n=8$, respectively; $P<0.0001$ ) (Figure $4 \mathrm{~b})$. Also, $\mathrm{Plg}^{+/-}$mice showed levels of leukocyte recruitment $\left(15.0 \pm 1.3 \times 10^{6}, n=8\right)$ intermediate to those found in $\mathrm{Plg}^{+/+}$and $\mathrm{Plg}^{-/-}$mice $\left(P<0.0001\right.$ vs. $\mathrm{Plg}^{+/+}$and $\left.P=0.007 \mathrm{vs} . \mathrm{Plg}^{-/}\right)$.

Leukocyte recruitment in the $\mathrm{Plg}^{+/-}$background was significantly affected by $\mathrm{PCPB}$ levels. As shown in Figure 4c, leukocyte levels in the $\mathrm{Plg}^{+/-} / \mathrm{PCPB}^{+/-}$and $\mathrm{Plg}^{+/-} / \mathrm{PCPB}^{-/-}$ mice were $23.8 \pm 2.1 \times 10^{6}(n=5)$ and $29.5 \pm 2.7 \times 10^{6}$ $(n=8)$, respectively, compared with $15.0 \pm 1.3 \times 10^{6}(n=8)$ in the $\mathrm{Plg}^{+/ /} / p \mathrm{CPB}^{+/+}$mice $(P=0.0004$ by ANOVA) (Figure $4 c)$. Thus, decreased $\mathrm{PCPB}$ activity also enhanced the cell migratory function of $\mathrm{Plg}$.

\section{Discussion}

In this study, we have inactivated the mouse PCPB gene to examine its role in modulating $\mathrm{Plg}$ functions in vivo. The primary approach used to accomplish this objective was to analyze the effects of different $\mathrm{pCPB}$ genotypes in a compromised $\mathrm{Plg}$ background; i.e., in $\mathrm{Plg}^{+/-}$mice that exhibit intermediate levels of fibrinolysis and cell migration. It was anticipated that this compromised background would be the most sensitive to modulatory effects of $\mathrm{pCPB}$ on Plg functions. The main finding of this study is that PCPB regulates primary functions of Plg in fibrinolysis and cell migration in vivo.

Numerous in vivo studies $(30,31,33,43)$ have shown that $\mathrm{PCPB}$ is an inhibitor of fibrinolysis, which depends primarily upon its capacity to remove carboxyterminal lysines from partially degraded fibrin, thereby eliminating an amplifying loop for Plg activation $(10,12)$. Some in vivo studies using inhibitors $(5,9,12$, 28) have also pointed to a physiological role for PCPB in regulating the fibrinolytic functions of $\mathrm{Plg}$. To more directly delineate the role of $P C P B$ in vivo, we generated mice with an inactivated $P C P B$ gene. Null expression of $\mathrm{PCPB}$ in the mice was confirmed by the absence of specific mRNA in the liver by Northern blot analysis and by absence of $\mathrm{PCPB}$ activity and antigen in plasma. The $p C P B$ deficiency did not appear to compromise embryonic development, viability, or life expectancy of the mice. No macroscopic anomalies were observed in the $p C P B$-deficient mice. While our manuscript was under consideration, Nagashima et al. (44) reported the development and characterization of $p C P B$-deficient mice. They also did not detect an overt phenotype and did not observe abnormal responses in these animals to a number of acute challenges. The similarity in phenotype is noteworthy since the targeting vectors used were quite different. In both studies, plasma derived from $p C P B$-deficient mice supported more rapid fibrinolysis compared with plasma derived from wild-type mice in vitro clot lysis assays, but this difference did not translate into a remarkable phenotype in the animals. In a preliminary report, Wagenaar et al. (45) also did not identify a phenotype in $P C P B$-deficient mice. This lack of overt effect is consistent with an absence of a dramatic phenotype in mice lacking PAI-1, another inhibitor of fibrinolysis (46).

To maximize the potential to detect a role of $\mathrm{pCPB}$ in the regulation of the functions of $\mathrm{Plg}$ in vivo, the effect of different $P C P B$ genotypes on fibrinolysis and cell migration was studied in a $\mathrm{Plg}^{+/-}$background, where either positive or negative modulation could be observed. In a pulmonary clot lysis model (14), $\mathrm{Plg}^{+/-}$ mice showed reduced levels of fibrinolysis compared with wild-type mice. Partial or total absence of $\mathrm{PCPB}$ increased fibrinolysis in the $\mathrm{Plg}^{+/-}$background to that found in $\mathrm{Plg}^{+/+}$mice. $\mathrm{pCPB}{ }^{+/-}$mice showed intermediate 
levels of fibrinolysis, pointing to a gene-dosage effect of $\mathrm{pCPB}$ in the inhibition of fibrinolysis. $\mathrm{PCPB}$ was also studied with regard to the role of Plg in cell migration. Leukocyte migration in response to thioglycollate is severely compromised in the $\mathrm{Plg}^{-1-}$ mice (17). In this model, the predominant cell type present at 72 hours is the monocyte/macrophage with a small contribution from lymphocytes. Total leukocyte recruitment to the peritoneum 72 hours after thioglycollate injection was increased in $P \mathrm{CPB}^{+/-}$and was enhanced still further in the $\mathrm{PCPB}^{-/-}$mice in a $\mathrm{Plg}^{+/-}$background to levels found in $\mathrm{Plg}^{+/+}$mice. The reduced monocyte/macrophage response to thioglycollate in $\mathrm{Plg}^{-/-}$mice is not due to diminished numbers of circulating monocytes (17) and is likely to be a consequence of the reduced binding of $\mathrm{Plg}$ to the surface of the migrating cells. This interpretation is consistent with the increased association of Plg with recruited inflammatory cells (47) and candidate $\mathrm{Plg}$ receptors on leukocytes from leukemic patients (48). Also, in a bleomycin model of lung injury (49), inflammatory cell recruitment was altered in the $\mathrm{Plg}^{-1-}$ mice. The role of $\mathrm{pCPB}$ in cell migration may reside in its removal of carboxy-terminal lysines, which serve as the Plg-binding sites on cell surfaces (28), or in its suppression of plasminogen activation, which blunts matrix degradation and the generation of chemoattractants, including fibrin derivatives $(50,51)$ and plasmin, itself (52).

With normal plasma levels of Plg, we found that plasma from $p C P B$-deficient mice supported only a modest increase in fibrinolysis compared with plasma from wild-type animals in vitro. In similar fibrinolysis assays using human plasma, neutralization or depletion of $\mathrm{pCPB}$ resulted in a more profound acceleration of clot lysis (28). One possible basis for this difference lies in the species specificities of the reagents used in the assays (e.g., human t-PA was used in these assays, and it activates mouse Plg slowly, compared with human Plg) (53). However, Marx et al. (7) suggested that purified mouse $\mathrm{PCPB}$ seemed less efficient that the human protein. Furthermore, no significant difference in fibrinolysis was observed between $p C P B$ deficient and wild-type mice in our in vivo pulmonary clot lysis assay. In a preliminary report (54), Biemond et al. also found no difference between $p C P B^{+/+}$and $p C P B^{-/-}$mice in a pulmonary clot lysis model. Also, Nagashima et al. (44) found no significant difference between the $p C P B^{-/-}$mice and their $p C P B^{+/+}$littermates in a variety of in vivo models. These results contrast with studies conducted in other animal species in which neutralization of $\mathrm{PCPB}$ was shown to accelerate fibrinolysis $(31,33)$. Thus, the possibility must be considered that $\mathrm{PCPB}$ may play a less prominent role in regulating fibrinolysis in the mouse. Alternatively, it may be the ratio of PCPB to Plg that is important in determining its role in regulating fibrinolysis. Assuming that the specific activity of mouse and human PCPB are similar, the level of PCPB in mouse plasma is about half that in human plasma, and the effect of $p C P B$ deficiency became apparent when the level of mouse Plg was reduced to 50\% in the $\mathrm{Plg}^{+/-}$mouse. In an in vitro fibrinolysis assay similar to that described in this study, we did not detect significant differences in the time for clot lysis in plasma from $p C P B^{+/+}$or $\mathrm{PCPB}^{-/-}$mice in the $\mathrm{Plg}^{+/-}$background. Taken together, these data do not exclude that $P C P B$ deficiency can lead to an overt defect in the function of Plg in vivo in an appropriate model but suggest that this model is likely to be one in which the functions of Plg are stressed. This is also likely to be the circumstance under which functions of PCPB become accentuated in other species as well. In humans, consumption of $\mathrm{Plg}$ can occur during disseminated intravascular coagulation or thrombolytic therapy. Changes in $\alpha 2$-antiplasmin, plasminogen activator, or PAI-1 levels also could distort Plg activation.

In summary, mice lacking $P C P B$ showed no lifethreatening phenotypes. However, the study of alterations in the $P C P B$ gene dosage in a $\mathrm{Plg}^{+/-}$background delineates a clear physiological role for $\mathrm{pCPB}$ as a modulator of the functions of Plg in vivo. Specifically, pCPB inhibits the fibrinolytic and cell migratory functions of Plg in a gene dosage-dependent manner. The pCPB levels vary greatly in humans (55), and such variations can be a mild risk factor for venous thrombosis $(37,56,57)$ and could influence the response to thrombolytic therapy. As proposed previously $(34,58)$, the regulation of $\mathrm{PCPB}$ could present a way of improving thrombolytic therapy. The absence of a notable phenotype in $P C P B$-deficient mice suggests that inhibition of PCPB should not be associated with severe pathogenic side effects.

\section{Acknowledgments}

We thank David Hellard, Carla Drumm, and Shying Wang for technical assistance; Ken Refino and Geralyn DeGuzman for in vitro fibrinolysis experiments; and Jane Rein for preparation of the manuscript. These studies were supported in part by NIH grant HL-17964. C.M. Swaisgood was supported by NIH grant HL-07914.

1. Eaton, D.L., Malloy, B.E., Tsai, S.P., Henzel, W., and Drayna, D. 1991. Isolation, molecular cloning, and partial characterization of a novel carboxypeptidase B from human plasma. J. Biol. Chem. 266:21833-21838.

2. Hendriks, D., Scharpe, S., van Sande, M., and Lommaert, M.P. 1989. Characterization of a carboxypeptidase in human serum distinct from carboxypeptidase N. J. Clin. Chem. Clin. Biochem. 27:277-285.

3. Wang, W., Hendriks, D.F., and Scharpé, S.S. 1994. Carboxypeptidase U, a plasma carboxypeptidase with high affinity for plasminogen. J. Biol. Chem. 269:15937-15944.

4. Campbell, W., and Okada, H. 1989. An arginine specific carboxypeptidase generated in blood during coagulation or inflammation which is unrelated to carboxypeptidase $\mathrm{N}$ or its subunits. Biochem. Biophys. Res. Commun. 162:933-939.

5. Bajzar, L., Manuel, R., and Nesheim, M.E. 1995. Purification and characterization of TAFI, a thrombin-activable fibrinolysis inhibitor. J. Biol. Chem. 270:14477-14484.

6. Vanhoof, G., Schatteman, K., Goossens, F., Scharpe, S., and Hendricks, D.F. 1997. Procarboxypeptidase $U$ is expressed in human liver. Fibrinolysis \& Proteolysis. 11:41.

7. Marx, P.F., et al. 2000. Characterization of mouse thrombin-activatable fibrinolysis inhibitor. Thromb. Haemost. 83:297-303.

8. Tan, A.K., and Eaton, D.L. 1995. Activation and characterization of procarboxypeptidase B from human plasma. Biochemistry. 34:5811-5816.

9. Bajzar, L., Morser, J., and Nesheim, M. 1996. TAFI, or plasma procar- 
boxypeptidase B, couples the coagulation and fibrinolytic cascades through the thrombin-thrombomodulin complex. J. Biol. Chem. 271:16603-16608.

10. Sakharov, D.V., Plow, E.F., and Rijken, D.C. 1997. On the mechanism of the antifibrinolytic activity of plasma carboxypeptidase B. J. Biol. Chem. 272:14477-14482.

11. Schatteman, K.A., Goossens, F.J., Scharpe, S.S., and Hendriks, D.F. 2000. Proteolytic activation of purified human procarboxypeptidase U. Clin. Chim. Acta. 292:25-40.

12. Wang, W., Boffa, M.B., Bajzar, L., Walker, J.B., and Nesheim, M.E. 1998. A study of the mechanism of inhibition of fibrinolysis by activated thrombin-activable fibrinolysis inhibitor. J. Biol. Chem. 273:27176-27281.

13. Bugge, T.H., Flick, M.J., Daugherty, C.C., and Degen, J.L. 1995. Plasminogen deficiency causes severe thrombosis but is compatible with development and reproduction. Genes Dev. 9:794-807.

14. Ploplis, V.A., et al. 1995. Effects of disruption of the plasminogen gene in mice on thrombosis, growth and health. Circulation. 92:2585-2593.

15. Lijnen, H.R., et al. 1996. Restoration of thrombolytic potential in plasminogen-deficient mice by bolus administration of plasminogen. Blood. 88:870-876.

16. Carmeliet, P., Moons, L., Ploplis, V., Plow, E., and Collen, D. 1997. Impaired arterial neointima formation in mice with disruption of the plasminogen gene. J. Clin. Invest. 99:200-208.

17. Ploplis, V.A., French, E.L., Carmeliet, P., Collen, D., and Plow, E.F. 1998. Plasminogen deficiency differentially affects recruitment of inflammatory cell populations in mice. Blood. 91:2005-2009.

18. Plow, E.F., Ploplis, V.A., Carmeliet, P., and Collen, D. 1999. Plasminogen and cell migration in vivo. Fibrinolysis \& Proteolysis. 13:49-53.

19. Creemers, E., et al. 2000. Disruption of the plasminogen gene in mice abolishes wound healing after myocardial infarction. Am. J. Pathol. 156:1865-1873.

20. Lerch, P.G., Rickli, E.E., Lergier, W., and Gillessen, D. 1980. Localization of individual lysine-binding regions in human plasminogen and investigations on their complex-forming properties. Eur. J. Biochem. 107:7-13.

21. Thorsen, S. 1975. Differences in the binding to fibrin of native plasminogen and plasminogen modified by proteolytic degradation influence of omega-aminocarboxylic acids. Biochim. Biophys. Acta. 393:55-65.

22. Thorsen, S., Clemmensen, I., Sottrup-Jensen, L., and Magnusson, S. 1981. Adsorption to fibrin of native fragments of known primary structure from human plasminogen. Biochim. Biophys. Acta. 668:377-387.

23. Lucas, M.A., Straight, D.L., Fretto, L.J., and McKee, P.A. 1983. The effects of fibrinogen and its cleavage products on the kinetics of plasminogen activation by urokinase and subsequent plasmin activity. J. Biol. Chem. 258:12171-12177.

24. Miles, L.A., and Plow, E.F. 1987. Receptor mediated binding of the fibrinolytic components, plasminogen and urokinase, to peripheral blood cells. Thromb. Haemost. 58:936-942.

25. Miles, L.A., Dahlberg, C.M., and Plow, E.F. 1988. The cell-binding domains of plasminogen and their function in plasma. J. Biol. Chem. 263:11928-11934

26. Miles, L.A., et al. 1991. Role of cell-surface lysines in plasminogen binding to cells: identification of alpha-enolase as a candidate plasminogen receptor. Biochemistry. 30:1682-1691.

27. Wiman, B., Lijnen, H.R., and Collen, D. 1979. On the specific interaction between the lysine-binding sites in plasmin and complementary sites in alpha-2-antiplasmin and in fibrinogen. Biochim. Biophys. Acta. 579:142-154.

28. Redlitz, A., Tan, A.K., Eaton, D.L., and Plow, E.F. 1995. Plasma carboxypeptidases as regulators of the plasminogen system. J. Clin. Invest. 96:2534-2538.

29. Stewart, R.J., Fredenburgh, J.C., Rischke, J.A., Bajzar, L., and Weitz, J.I. 2000. Thrombin-activable fibrinolysis inhibitor attenuates (DD)E-mediated stimulation of plasminogen activation by reducing the affinity of (DD)E for tissue plasminogen activator. A potential mechanism for enhancing the fibrin specificity of tissue plasminogen activator. J. Biol. Chem. 275:36612-36620.

30. Redlitz, A., Nicolini, F.A., Malycky, J.L., Topol, E.J., and Plow, E.F. 1996. Inducible carboxypeptidase activity. A role in clot lysis in vivo. Circulation. 93:1328-1330.

31. Minnema, M.C., et al. 1998. Enhancement of rabbit jugular vein thrombolysis by neutralization of factor XI. In vivo evidence for a role of factor XI as an anti- fibrinolytic factor. J. Clin. Invest. 101:10-14.

32. Von dem Borne, P.A.K., Bajzar, L., Meijers, J.C.M., Nesheim, M.E., and Bouma, B.N. 1997. Thrombin-mediated activation of factor XI results in a thrombin-activatable fibrinolysis inhibitor-dependent inhibition of fibrinolysis. J. Clin. Invest. 99:2323-2327.
33. Nagashima, M., et al. 2000. An inhibitor of activated thrombin-activatable fibrinolysis inhibitor potentiates tissue-type plasminogen activatorinduced thrombolysis in a rabbit jugular vein thrombolysis model. Thromb. Res. 98:333-342.

34. Klement, P., Liao, P., and Bajzar, L. 1999. A novel approach to arterial thrombolysis. Blood. 94:2735-2743.

35. Gresele, P., et al. 1998. Activated human protein O prevents thrombininduced thromboembolism in mice. Evidence that activated protein $\mathrm{C}$ reduces intravascular fibrin accumulation through the inhibition of additional thrombin generation. J. Clin. Invest. 101:667-676.

36. Mosnier, L.O., Von dem Borne, P.A.K., Meijers, J.C.M., and Bouma, B.N. 1998. Plasma TAFI levels influence the clot lysis time in healthy individuals in the presence of an intact intrinsic pathway of coagulation. Thromb. Haemost. 80:829-835.

37. Van Tilburg, N.H., Rosendaal, F.R., and Bertina, R.M. 2000. Thrombin activatable fibrinolysis inhibitor and the risk for deep vein thrombosis. Blood. 95:2855-2859.

38. Nagy, A., Rossant, J., Nagy, R., Abramow-Newerly, W., and Roder, J.C. 1993. Derivation of completely cell culture-derived mice from early-passage embryonic stem cells. Proc. Natl. Acad. Sci. USA. 90:8424-8428.

39. Bradley, A. 1987. Production and analysis of chimaeric mice: teratocarcinomas and embryonic stem cells: a practical approach. IRL Press. Oxford, United Kingdom. 113-151.

40. Laird, P.W., et al. 1991. Simplified mammalian DNA isolation procedure. Nucleic Acids Res. 19:4293. (Abstr.)

41. Sambrook, J., Fritsch, E.F., and Maniatis, T. 1989. Molecular cloning: a laboratory manual. Cold Spring Harbor Press. Cold Spring Harbor, New York, USA. 7.43-7.50

42. Bugge, T.H., Flick, M.J., Daugherty, C.C., and Degen, J.L. 1995. Plasminogen deficiency causes severe thrombosis but is compatible with development and reproduction. Genes Dev. 9:794-807.

43. Nesheim, M.E. 1999. TAFI. Fibrinolysis \& Proteolysis. 13:72-77.

44. Nagashima, M., et al. 2002. Thrombin-activatable fibrinolysis inhibitor (TAFI) deficiency is compatible with murine life. J. Clin. Invest. 109:101-110. doi:10.1172/JCI200212119.

45. Wagenaar, G.T.M., et al. 2001. Generation and characterization of thrombin activatable fibrinolysis inhibitor deficient mice. Thromb. Haemost. (Suppl.):OC1759. (Abstr.)

46. Carmeliet, P., et al. 1993. Plasminogen activator inhibitor-1 gene-deficient mice. II. Effects on hemostasis, thrombosis, and thrombolysis. J. Clin. Invest. 92:2756-2760.

47. Herren, T., Burke, T.A., Jardi, M., Felez, J., and Plow, E.F. 2001. Regulation of plasminogen binding to neutrophils. Blood. 97:1070-1078.

48. Menell, J.S., et al. 1999. Annexin II and bleeding in acute promyelocytic leukemia. N. Engl.J. Med. 340:994-1004.

49. Swaisgood, C.M., French, E.L., Noga, C., Simon, R.H., and Ploplis, V.A. 2000. The development of bleomycin-induced pulmonary fibrosis in mice deficient components of the fibrinolytic system. Am. J. Pathol. 157:177-187.

50. Richardson, D.L., Pepper, D.S., and Kay, A.B. 1976. Chemotaxis for human monocytes by fibrinogen-derived peptides. Br. J. Haematol. 32:507-513.

51. Leavell, K.J., Peterson, M.W., and Gross, T.J. 1996. The role of fibrin degradation products in neutrophil recruitment to the lung. Am.J. Respir. Cell Mol. Biol. 14:53-60.

52. Syrovets, T., Thillet, J., Chapman, M.J., and Simmet, T. 1997. Lipoprotein(a) is a potent chemoattractant for human peripheral monocytes. Blood. 90:2027-2036.

53. Lijnen, H.R., Van Hoef, B., Beelen, V., and Collen, D. 1994. Characterization of the murine plasma fibrinolytic system. Eur. J. Biochem. 224:863-871.

54. Biemond, B.J., Havik, S., and Meijers, J.C.M. 2001. Absence of enhanced endogenous lysis of pulmonary microemboli in TAFI deficient mice. Blood. 98:255a. (Abstr.)

55. Chetaille, P., Alessi, M.C., Kouassi, D., Morange, P.E., and Juhan-Vague, I. 2000. Plasma TAFI antigen variations in healthy subjects. Thromb. Haemost. 83:902-905.

56. Franco, R.F., et al. 2001. Identification of polymorphisms in the 5'untranslated region of the TAFI gene: relationship with plasma TAFI levels and risk of venous thrombosis. Haematologica. 86:510-517.

57. Tregouet, D.A., et al. 2001. Combined segregation-linkage analysis of plasma thrombin activatable fibrinolysis inhibitor (TAFI) antigen levels with TAFI gene polymorphisms. Hum. Genet. 109:191-197.

58. Stefansson, S., Lawrence, D.A., Herren, T., and Plow, E.F. 1998. Novel approaches to thrombolysis based on modulation of endogenous fibrinolysis. Coron. Artery Dis. 9:99-104. 